\title{
Host ranges of Penicillium species causing blue mold of bulb crops in Washington State and Idaho
}

F.M. Dugan ${ }^{\mathrm{a}^{*}}$, S.L. Lupien ${ }^{\mathrm{a}}$, C.M. Vahling-Armstrong ${ }^{\mathrm{bl}}{ }^{\text {, G.A. Chastagner }}{ }^{\mathrm{c}}$, and B.K. Schroeder ${ }^{\mathrm{d}}$ ${ }^{a}$ USDA-ARS Western Regional Plant Introduction Station, 59 Johnson Hall, Washington State University, Pullman WA 99164-6402 USA

${ }^{\mathrm{b}}$ Department of Plant Pathology, Washington State University, Pullman WA

${ }^{\mathrm{c}}$ Department of Plant Pathology, Washington State University, Puyallup WA USA

${ }^{\mathrm{d}}$ Plant, Soil and Entomological Sciences, University of Idaho, Moscow ID USA

*Corresponding author.

E-mail address: fdugan@wsu.edu (F.M. Dugan).

Key words

Blue mold, garlic, iris, onion, ornamental onion, Penicillium albocoremium, $P$. crustosum, $P$. expansum, $P$. glabrum, $P$. paraherquei, $P$. polonicum, $P$. radicicola, taxonomy, tulip

\begin{abstract}
First reported from the Pacific Northwest of U.S.A. as causal agents of blue mold on edible and/or ornamental bulbs are Penicillium albocoremium (from Tulipa sp.; pathogenic on Allium sativum, A. cepa, A. stipitatum, Iris hollandica and Tulipa sp.), P. crustosum (from Narcissus;
\end{abstract}

\footnotetext{
Present address: USDA-ARS Subtropical Plant Pathology Research, Fort Pierce, FL 34945 USA
} 
pathogenic on A. cepa and I. hollandica), P. paraherquei (from A. cepa; pathogenic on A. sativum and A. cepa), and P. radicicola (from Iris Casablanca; pathogenic on A. sativum, A. cepa and I. hollandica). Penicillium expansum and P. glabrum, from A. cepa, were verified as pathogens of A. sativum, A. cepa and Iris hollandica, and P. expansum was also pathogenic on Tulipa sp. Pronounced differences between Penicillium agents of blue mold in host range and in virulence have implications for crop rotation, postharvest storage and marketing.

\section{Introduction}

In recent years there have been advances in documenting taxonomy and behavior of species of Penicillium causing blue mold of edible and ornamental bulb crops. Extensive collections of Penicillium species of the section Viridicata, many formerly placed in series Corymbifera (essentially segregates of $P$. corymbiferum Westling, syn. $=P$. hirsutum Dierckx) and primarily from Europe, have been extensively researched by Overy et al. (2005a, 2005b, 2005c). A collection of lesser depth but exclusively from the United States and concentrated in the Pacific Northwest (PNW) has been similarly addressed (Dugan et al., 2011, 2014) with a detailed synopsis of taxonomy and nomenclature (Dugan et al., 2014).

As early as Smalley and Hanson (1962) there were indications that Penicillium isolates causing blue mold of a given bulb crop (garlic in that instance) and overtly similar in morphology and cultural characters were not all of the same taxon. Such isolates have subsequently been shown to differ in host range, environmental preference and species assignment (Dugan et al., 2011, 2014; Overy et al., 2005a, 2005b, 2005c). We have received anecdotal information from horticulturists that additional Penicillium taxa are involved in bulb rots, and also have recovered from regional bulb crops Penicillium taxa not listed as attacking 
these hosts in extant literature, or at least novel with regard to the PNW.

New isolates from the PNW were provisionally assigned to two species inside the traditional series Corymbifera ( $P$. albocoremium and $P$. radicicola), to $P$. crustosum (series Camemberti), $P$. expansum (series Expansa) and $P$. polonicum (series Viridicata), all in subgenus Penicillium section Viridicata (= section Fasciculata) (Frisvad and Samson 2004; Houbracken et al., 2011). We also recovered isolates provisionally assigned to P. glabrum, traditionally placed in subgenus Aspergilloides section Aspergilloides, or to $P$. paraherquei in subgenus Furcatum section Furcatum (Pitt 2000). Assignment of P. parahequei to section has been recently revised to section Lanata-Divaricata (Visagie et al., 2014).

Given the management implications of these findings, we resolved to confirm identifications, and to use these additional isolates recovered from edible Allium and ornamental bulb crops in our region for further investigations of host ranges. Intra-specific variability in pathogenicity was largely not assessed due to lack of multiple, well-identified isolates of a single taxon from regional (PNW) bulbs, but see remarks on $P$. polonicum below (4.2).

\section{Materials and Methods}

\subsection{Fungal isolates}

Isolates (Table 1) were recovered by us either from field surveys of onion (VahlingArmstrong, Schroeder) in Central Washington State in 2010, from ornamental bulbs surveyed in Western Washington State (Chastagner), from bulbs obtained in local retail outlets in northcentral Idaho (Dugan, Lupien), or solicited from extant collections of colleagues working with commercial onion seed. Accession number incorporates year of collection (Table 1). Species name reflects final determination (Results). All isolates are deposited with the USDA-ARS 
(NRRL) Culture Collection in Peoria, IL.

Table 1. Fungal isolates used in this study

\begin{tabular}{|c|c|c|c|}
\hline Penicillium species & $\begin{array}{l}\text { Accession } \\
\text { Numbers }\end{array}$ & $\begin{array}{l}\text { Isolation } \\
\text { Host }\end{array}$ & $\begin{array}{l}\text { Isolation } \\
\text { Locale }\end{array}$ \\
\hline P. albocoremium (Frisvad) Frisvad & $\begin{array}{l}\text { PenVDC36:2013 } \\
\text { NRRL 66387 }\end{array}$ & $\begin{array}{l}\text { tulip 'Verandi D' } \\
\text { tulip petal }\end{array}$ & $\begin{array}{l}\text { Washington } \\
\text { State }\end{array}$ \\
\hline P. crustosum Thom & $\begin{array}{l}\text { PenYC\#1:2011 } \\
\text { NRRL 66388 }\end{array}$ & $\begin{array}{l}\text { 'Yellow Cheer' daffodil } \\
\text { bulb }\end{array}$ & $\begin{array}{l}\text { Washington } \\
\text { State }\end{array}$ \\
\hline P. expansum Link & $\begin{array}{l}\text { Pen347-W:2010 } \\
\text { NRRL } 66389\end{array}$ & $\begin{array}{l}\text { Allium cepa } \\
\text { bulb }\end{array}$ & $\begin{array}{l}\text { Washington } \\
\text { State }\end{array}$ \\
\hline P. glabrum (Wehmer) Westling & $\begin{array}{l}\text { OPen\#15:2011 } \\
\text { NRRL 66390 }\end{array}$ & $\begin{array}{l}\text { A. cepa 'Gold Pearl' } \\
\text { bulb }\end{array}$ & Idaho \\
\hline P. paraherquei S. Abe ex G. Sm. & $\begin{array}{l}\text { Pen308-N:2010 } \\
\text { NRRL 66391 }\end{array}$ & $\begin{array}{l}\text { A. сера 'Ranchero' } \\
\text { bulb }\end{array}$ & $\begin{array}{l}\text { Washington } \\
\text { State }\end{array}$ \\
\hline P. polonicum K.M. Zalesky & $\begin{array}{l}\text { Pen1:2010 } \\
\text { NRRL } 66385\end{array}$ & $\begin{array}{l}\text { A. cepa 'Prince' } \\
\text { seed }\end{array}$ & $\begin{array}{l}\text { Washington } \\
\text { State }\end{array}$ \\
\hline P. radicicola Overy \& Frisvad & $\begin{array}{l}\text { PenCB\#1:2011 } \\
\text { NRRL } 66386\end{array}$ & $\begin{array}{l}\text { 'Casablanca' iris } \\
\text { bulb }\end{array}$ & $\begin{array}{l}\text { Washington } \\
\text { State }\end{array}$ \\
\hline
\end{tabular}

Fungal isolates were assessed for conformity with standard descriptions (Pitt 1979, 2000; Frisvad and Samson 2004) by inoculation of single-conidium strains to Czapeck yeast agar at 25 ${ }^{\circ} \mathrm{C}$ and $30{ }^{\circ} \mathrm{C}$, malt extract agar, creatine sucrose agar, and yeast extract sucrose agar at $25^{\circ} \mathrm{C}$, and recording of microscopic characters. Identity was confirmed on the basis of $\beta$-tubulin sequences (Houbraken et al., 2016; Khodaei et al., 2015; Samson et al., 2004, Sanzani et al., 2016). Isolates were grown on $1 / 2 \mathrm{~V} 8$ agar, conidia washed from the agar surface and pelleted by centrifugation, washed twice with sterile water, and the pellet lyophilized, and stored at room temperature until DNA extraction. Lyophilized conidial pellets were disrupted in the presence of 3-mm glass beads 
in a Fast Prep ${ }^{\mathrm{TM}} 120$ cell disruptor (speed 6 for 30 s). Genomic DNA was isolated immediately following tissue disruption using Qiagen DNeasy ${ }^{\circledR}$ Plant Mini Kit (Qiagen, Valencia, CA) following the manufacturer's instructions. DNA was eluted from the column with $100 \mathrm{ml}$ of sterile water. Amplification of the $\beta$-tubulin partial gene sequence was accomplished using primers Bt2a-F and Bt2b-R (Glass and Donaldson, 1995). PCR was conducted in $100 \mu$ reaction mixtures containing 2 to $10 \mu \mathrm{l}$ of genomic DNA extract, $20 \mu \mathrm{l}$ of GoTaq $5 \mathrm{X}$ reaction buffer, $2 \mu \mathrm{l}$ of $10 \mathrm{~mm}$ dNTP mix, $3 \mu \mathrm{l}$ of $25 \mathrm{mM} \mathrm{MgCl} 2,50$ pmol of each primer, and $1 \mu \mathrm{l}$ of $\mathrm{GoTaq}^{\circledR}$ polymerse (Promega, Madison, WI). Amplifications were performed in a Veriti ${ }^{\circledR}$ 96-well thermal cycler under 9700 max mode ramping with an initial denaturation at $95{ }^{\circ} \mathrm{C}$ for 4 min followed by 5 cycles of denaturation at $94{ }^{\circ} \mathrm{C}$ for $1 \mathrm{~min}$, step down annealing $1{ }^{\circ} \mathrm{C}$ per cycle $(68$ ${ }^{0} \mathrm{C}$ to $64{ }^{\circ} \mathrm{C}$ ), and extension at $72{ }^{\circ} \mathrm{C}$ for 2 min followed by 30 cycles of $94{ }^{\circ} \mathrm{C}$ for $1 \mathrm{~min}, 64{ }^{\circ} \mathrm{C}$ for $90 \mathrm{sec}$, and $72{ }^{\circ} \mathrm{C}$ for $2 \mathrm{~min}$, plus a final elongation step of $10 \mathrm{~min}$ at $72{ }^{\circ} \mathrm{C}$. Amplified DNA was purified with Qiagen QIAquick ${ }^{\circledR}$ spin columns and sequenced on both strands using primers Bt2a and Bt2b (Glass and Donaldson, 1995). Additional primers were synthesized to obtain full sequence of the PCR amplicon in both directions. Sequencing reactions and primer synthesis were performed by Eurofins MWG/Operon (Huntsville, AL). Sequence data was assembled and aligned using Sequencher ${ }^{\mathrm{TM}} 5.4$ software (Gene Codes Corp. Ann Arbor, MI). Assembled partial gene sequences were aligned with $\beta$-tubulin sequences in GenBank, including authentic and type strains of Penicillium subgenus Penicillium (Samson et al., 2004) using BLASTN 2.2.21 software (Zhang et al., 2000).

\subsection{Inoculation hosts}

The following were experimental inoculation hosts: Allium sativum (garlic, Rose du Var 
W6 35682) from USDA-ARS-WRPIS (Pullman, WA); A. cepa (onion, Gold Pearl) from

Melissa's Produce (Los Angeles, CA); A. cepa (onion, Forum) from Bejo Seeds (Oceano, CA);

A. stipitatum (ornamental onion, PI 576941), WRPIS; Iris hollandica, Purple Sensation, originally from Dutch Grown (Glendale, CA) and subsequently produced in a WRPIS green house; Tulipa sp. Purple Prince from ADR Bulbs (Chester, NY) and subsequently produced in a WRPIS green house.

\subsection{Experimental design}

Each of the six hosts was inoculated with the seven fungal isolates (Table 1). Each treatment consisted of three replications, with each replication containing three bulbs or cloves. Controls for each treatment also contained three replications, each with a sample size of three bulbs or cloves. Each experiment was repeated once.

\subsection{Inoculum preparation, inoculation, incubation and measurement}

Isolates were revived from filter paper stocks onto $1 / 2 \mathrm{~V} 8$ agar, grown for 8-14 days at room temperature under diurnal (12 hrs/day) near-ultraviolet/cool white light, washed with sterile water, serially diluted, quantified on a hemocytometer, and adjusted to $1.5 \times 10^{5}$ conidia per $\mathrm{ml}$ in sterile $0.2 \%$ semi liquid agar. Inoculum was stored at $5{ }^{\circ} \mathrm{C}$ for $1-2$ days during conduct of a given experiment.

Plant host cloves (garlic) or bulbs were surface-disinfested prior to inoculation for 5 min in $0.5 \%$ sodium hypochlorite, rinsed three times for $5 \mathrm{~min}$ in sterile water and allowed to dry on sterile Kimwipes (Kimberly-Clark, Roswell, GA) in a biological safety cabinet overnight. Each bulb or clove was wounded on its side with a sterile probe creating a single wound $4 \mathrm{~mm}$ deep $\mathrm{x}$ 
$1 \mathrm{~mm}$ diam. Thirty five $\mu 1$ of inoculum, or in the case of controls $35 \mu \mathrm{l}$ of sterile semi-liquid agar, was applied to the wound site, and each treated bulb placed into an individual sterile container of appropriate size for a given host, with the lid of each container having a single $4 \mathrm{~mm}$ hole. Containers of a given host inoculated with a single fungal isolate, and the associated controls, were randomized within one incubation tray (Nalgene product 6900-0020) including a single $150 \mathrm{ml}$ tub of sterile water, and the incubation tray sealed with plastic wrap to maintain humidity at or above $90 \%$ during the incubation period. $\mathrm{HOBO}$ data loggers $\left(\mathrm{HOBO}^{\circledR}\right.$, Onset Computer Corp., Borne, MA) were placed inside of incubation trays in order to assure uniformity of conditions between experiments. Inoculated materials were incubated at room temperature (23-24 $\left.{ }^{\circ} \mathrm{C}\right)$, monitored for development of rot and incubated for 21-34 days, at which time the maximum diameter of each lesion developing on the wound site was measured and recorded from all hosts inoculated on a given date. Maximum lesion diameters present at the wound site, or simply the wound site itself in the absence of rot, were measured and recorded using Storm ${ }^{\mathrm{TM}}$ electronic calipers.

Re-isolation of isolates was attempted on two representative symptomatic bulbs or cloves per trial for those trials in which statistically significant decay was observed. Lesion margins were excised, surface disinfested, and plated to $1 / 2 \mathrm{~V} 8$ agar amended with $50 \mu \mathrm{g} / \mathrm{ml}$ streptomycin sulfate and tetracycline hydrochloride. Recovered single-conidium isolates were characterized by $\beta$-tubulin sequence analyses.

\subsection{Statistical analysis}

Lesion diameters were converted to rates of lesion expansion, ( $\mathrm{mm} / \mathrm{week})$ and used as the independent variable in T-tests conducted for each host-isolate pair (inoculated materials vs. 
controls) in order to assess pathogenicity of an isolate on a given host. Comparative virulence (aggressiveness) of isolates was analyzed as multiple pair-wise comparisons by General Linear Model (GLM). Analyses were conducted in Systat 13.10 (Systat Software, Inc., Chicago, IL), with GLM pair-wise comparisons grouped by treatment using post hoc test of Fisher's least significant difference $(\mathrm{LSD})$ and Error Term $=$ model mean square error (MSE).

\section{Results}

\subsection{Isolates}

No isolate strongly diverged from standard morpho-cultural descriptions for species determinations (Pitt 1979, 2000; Frisvad and Samson 2004) assigned largely on the basis of $\beta$ tubulin gene sequences specified below, although the reverse of PenVDC36:2013 on YES agar was more red-yellow than brown-yellow or orange.

Isolate Pen VDC36:2013 (GenBank KY172961) shared 100\% identity with $P$.

albocoremium ex-type CBS 47284 (Houbraken et al., 2016), and 99\% with that same isolate plus P. albocoremium CBS 109614 and CBS 109582, as sequenced by Samson et al. (2004). The next match was 99\% identity with $P$. hirsutum NRRL 999 (Dugan et al., 2014).

Isolate PenYC\#1:2011 (GenBank KY172962) shared 99\% identity with CBS 101025 and CBS 47184, determined as P. crustosum (Samson et al., 2004), each of which, as well as PenYC\#1:2011, were 97\% homologous with the type for P. crustosum, CBS 11503 (Samson et al., 2004). PenYC\#1:2011 had 100\% identity with P. crustosum ATHUM 5080 and DTO-266B3 (Khodaei et al., 2015), 98\% with P. solitum CBS 14786 (ex-type) and 97\% with CBS 14686 (also from Samson et al., 2004).

Isolate Pen347-W:2010 (GenBank 172963) shared 99\% identity with P. expansum ex- 
type CBS 32548 and CBS 48184, and CBS 28197, the latter two also determined as P. expansum in Samson et al. (2004). P. expansum strains ITEM 7026-RA6, ITEM 7027-RA7, ITEM 7028RA8, and ITEM 7030-P8 (Sanzani et al., 2016) each shared 100\% identity with Pen 347W:2010. Isolate OPen \#15:2011 (GenBank KY172964) was 100\% identical with P. glabrum CBS 229.28 (Barreto et al., 2011) and P. frequentans Westling DTO 053-F2 (Houbraken et al., 2014). The latter researchers re-introduced $P$. frequentans as a distinct species separate from $P$. glabrum with which it was formerly synonymous. Our isolate had $99 \%$ identity with other P. glabrum isolates from these same two publications.

Isolate Pen 308-N:2010 (GenBank KY172965) was 100\% identical with P. paraherquei ex-type CBS 430.65 (Houbraken et al., 2011; Park et al., 2014).

Isolate Pen1:2010 (GenBank KY172966) was 100\% identical with P. polonicum isolates G5314 (Chen et al. 2013) and D116-102 (Guevara-Suarez et al., in press); and shared 99\% identity with $P$. polonicum isolates CBS 101479 and CBS 69077 and 98\% identity with $P$. polonicum ex-type CBS 22228, all from Samson et al. (2004).

Isolate PenCB\#1:2011 (GenBank KY172967) had 99\% identity with P. radicicola CBS 109554, CBS 109551and ex-type CBS 112430 (Samson et al., 2004). PenCB\#1:2011 had 98\% identity with $P$. radicicola CBS $112425, P$. hirsutum ex-type CBS 13541, $P$. hirsutum strain NRRL 999, and P. tulipae CBS 111217 all from Samson et al. (2004).

\subsection{Host range and pathogenicity}

Summary reactions of hosts to individual isolates of recovered taxa are provided in Table 2 and an example of a positive result in Fig. 1. Means, standard deviations, and P values for paired T-tests and GLM are provided for all isolate-host challenges in Appendix A. 
In a small number of instances, quiescent fungi interfered with re-isolation of the inoculated agent, or there was a problem with viability (Appendix A), but re-isolation was always successful in a minimum of one trial and sporulation in lesions induced by inoculation was consistent between initial and repeat trials. Identity of inoculated agent was additionally confirmed by $\beta$-tubulin sequences except for the instances just specified (Appendix A) and was accomplished for each host-isolate pair in which the isolate induced lesions statistically differing from controls.

Table 2. Reactions of test bulbs to artificial inoculation in paired T-tests, inoculated vs. controls

\begin{tabular}{|c|c|c|c|c|c|c|}
\hline $\begin{array}{l}\text { Host } \rightarrow \\
\text { Penicillium spp. } \downarrow\end{array}$ & A. sativum & $\begin{array}{l}\text { A. сера } \\
\text { Gold Pearl }\end{array}$ & $\begin{array}{l}\text { A. сера } \\
\text { Forum }\end{array}$ & A. stipitatum & Iris hollandica & $\begin{array}{l}\text { Tulipa } \\
\text { Purple Prince }\end{array}$ \\
\hline P. albocoremium & + & + & + & \pm & + & + \\
\hline P. crustosum & - & + & + & - & \pm & - \\
\hline P. expansum & \pm & + & - & - & + & + \\
\hline P. glabrum & + & + & + & - & \pm & - \\
\hline P. paraherquei & + & - & + & - & - & - \\
\hline P. polonicum & + & + & + & - & - & - \\
\hline P. radicicola & + & + & + & - & + & - \\
\hline \multicolumn{7}{|c|}{$+=P \leq 0.05$ in both tests (pathogenicity supported) } \\
\hline$\pm=P \leq 0.05$ in & ne test al & $P \leq 0.10$ & e other $(1$ & ate support & r pathogenici & \\
\hline
\end{tabular}




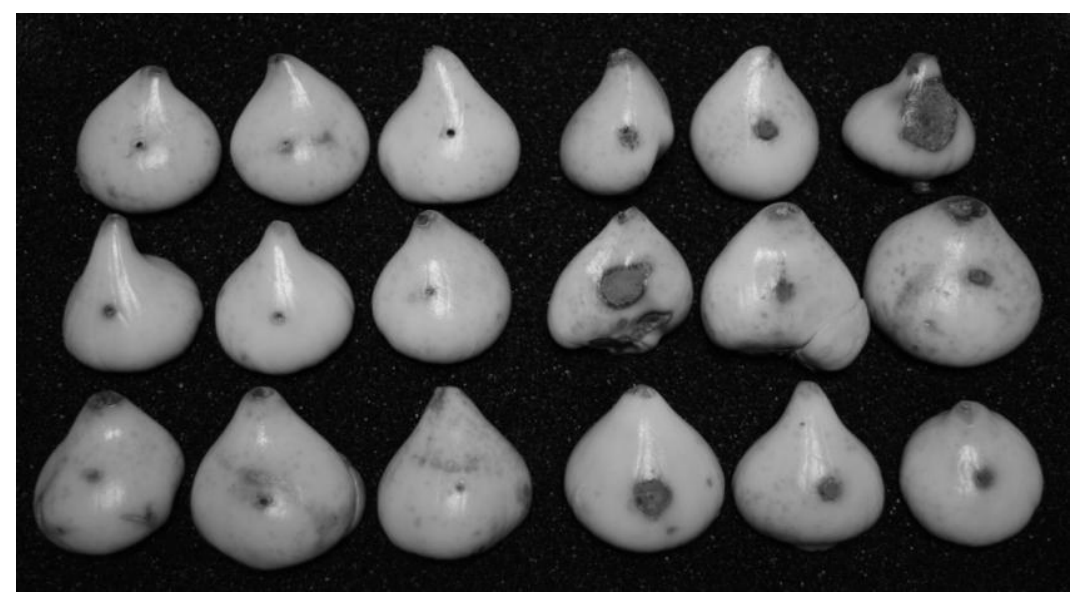

Figure 1. Penicillium albocoremium PenVDC36:2013 inoculated to tulip: Controls (left three columns), inoculated (right three columns) at 31 days post-inoculation and ambient laboratory temperature, illustrating a result of pathogenicity with moderate virulence.

\subsection{Lesion expansion and virulence}

Rates of lesion expansion (mm/week, mean of two replicated tests) for Penicillium species on the hosts to which they proved pathogenic (Table 2) were as follows: $P$. albocoremium (garlic 10.28; GP onion 7.90; Forum onion 6.57; ornamental onion 2.80; iris 2.20; tulip 2.34), P. crustosum (GP onion 0.98; Forum onion 1.00; iris 1.75), P. expansum (garlic 2.50; GP onion 0.85; iris 2.33; tulip 2.21), P. glabrum (garlic 3.41; GP onion 1.14; Forum onion 0.89; iris 1.68), P. paraherquei (garlic 2.52; Forum onion 0.88), P. polonicum (garlic 9.76; GP onion 5.87; Forum onion 5.65), P. radicicola (garlic 6.15; GP onion 2.92; Forum onion 4.56; iris 1.88).

For species of demonstrated pathogenicity in paired T-tests (Table 2), and differing from each other in virulence (aggressiveness) at $P \leq 0.05$ in multiple pair-wise comparisons (GLM), $P$. albocoremium and $P$. polonicum, followed by $P$. radicicola, were the most virulent on garlic, with $P$. albocoremium most virulent in one test and $P$. polonicum most virulent in the repeat. On 
Gold Pearl onion, order of virulence (highest to lowest) was $P$. albocoremium, $P$. polonicum and P. radicicola; $P$. glabrum was consistently of intermediate virulence among remaining pathogenic species. On Forum onion, P. albocoremium was consistently most virulent. On iris, P. albocoremium and P. expansum were most virulent, and did not statistically differ, while the next most virulent, $P$. radicicola, consistently differed from $P$. albocoremium only at $P \leq 0.10$. Penicillium albocoremium and $P$. expansum did not consistently differ in virulence on tulip. All other differences in virulence were either statistically insignificant or the order of virulence was inconsistent between tests (data not shown).

\section{Discussion}

\subsection{Behavioral differences of isolates}

Penicillium albocoremium (P. hirsutum var. albocoremium Frisvad) differed from $P$. radicicola in host preference (Table 2, Fig. 1) and aggressiveness, even though both are traditionally in series Corymbifera and very closely related (Frisvad and Samson 2004). "No significant micromorphological variation exists between $P$. albocoremium [and] $P$. radicicola" but the latter, segregated in 2003 from the former, differs in secondary metabolites and some other characters (Overy and Frisvad 2003). Penicillium radicicola was referenced with "Similar species: See P. albocoremium" in Frisvad and Samson (2004). Although series Corymbifera is not strictly phylogenetic, all members are in section Viridicata (Fasciculata) and with the exception of $P$. hordei (occurring mostly on barley), are united by a habit of infecting bulb crops. Our findings represent further confirmation that species in this series may differ in host range. Isolates of both species are recorded from Allium spp. in Denmark (Frisvad and Samson 2004). To our knowledge, this constitutes the first report of $P$. albocoremium and $P$. radicicola from 
bulb crops in North America. Penicillium albocoremium was the only agent to induce blue mold on A. stipitatum (other species failed to do so, see Dugan et al., 2011, 2014), but support for pathogenicity was only moderate $( \pm)$.

\subsection{Distributions on bulb crops}

Penicillium crustosum is documented from "mouldy onion" in Denmark (Sonjak et al., 2005). Varieties in P. aurantiogriseum Dierckx or P. expansum have previously been listed as synonyms of $P$. crustosum (Pitt 1979), but $P$. crustosum is distinct from $P$. aurantiogriseum and P. expansum under current concepts, and is sister to a clade containing $P$. solitum Westling (Frisvad and Samson 2004). We believe this to be the first report of $P$. crustosum on bulb crops in North America.

Penicillium expansum is reported on onion without geographical attribution (Sumner et al., 2008), from New Zealand and (as P. glaucum Link) from China (Farr and Rossman n.d.), from onion in Lithuania (Lugauskas et al., 2005), and from onion and garlic in Korea (Yu et al., 1997). Reports from ornamental bulbs are less frequent; it is reported from unspecified species or cultivars of Lilium bulbs from India, but without specifying method of identification (HemaMoorthy and Prakasam 2013). The name has been applied to isolates rotting onion in Washington State (John Fellman, personal communication; Stevens et al., 2006) but to our knowledge this is the first instance from Washington State of identification using either stringent morpho-cultural criteria or molecular-genetic criteria for putative $P$. expansum on any of our hosts, including A. cepa. Noteworthy is the difference in varietal susceptibility of onion, with Gold Pearl susceptible, and Forum resistant to our isolate. 
Penicillium glabrum is documented as a pathogen of onion, but is usually restricted to outer layers (Frisvad et al., 2007, with literature review). Varga et al. (2008) specified $P$. glabrum on onion. Some specimens (e.g. IMI 374732) have been recovered from ornamental bulbs (Narcissus, www.herbimi.info), and $P$. frequentans (often placed in synonymy with $P$. glabrum), identified on morpho-cultural criteria, was isolated repeatedly from commercial tulip bulbs in Poland (Piwani 2007). The closely related (and morphologically similar) Penicillium spinulosum Thom has been isolated from onion bulbs in Lithuania (Lugauskas et al., 2005). Penicillium glabrum and related species are recently examined by molecular-genetic and morpho-cultural criteria (Barreto et al., 2011; Houbraken et al., 2014). We know of no previous reports of $P$. glabrum on edible or ornamental bulbs from the PNW.

Penicillium paraherquei (as well as $P$. brasilianum Bat.) was previously considered a synonym of $P$. simplicissimum (Oudem.) Thom (Pitt 1979, 2000). Isolates identified as $P$. simplicissimum on the basis of morphological criteria using Pitt (1979) are recorded from onion in Pakistan (Ibatsam et al., 2012). Penicillium brasilianum is recorded on onion in Korea, and was distinguished from P. simplicissimum by multi-gene topology (Sang et al., 2014). Penicillium paraherquei and P. brasilianum are sister taxa by multi-gene topology (Oh et al., 2015, reporting on P. georgiense S.W. Peterson \& B.W. Horn as a pathogen of onion). Mansouri et al. (2013) show P. paraherquei and $P$. brasilianum as sister taxa by multi-gene topology, in a clade sister to $P$. simplicissimum. To our knowledge, this is the first report of $P$. paraherquei on edible or ornamental bulbs in North America.

Our assay for P. polonicum obtained the same result as in Dugan et al. (2014), except that in 2014 the isolate used (not identical to the isolate here but also from seed of onion cultivar 'Prince') was \pm (not -) on iris. Penicillium polonicum is reported from onion in Serbia (Duduk et 
al., 2014), Turkey (Çakir and Maden, 2015), and from each of our hosts in Dugan et al. (2014).

Pencillium polonicum (= P. aurantiogriseum var. polonicum (K.M. Zaleski) Frisvad \& Filt.) was once considered a synonym of $P$. aurantiogriseum, as were $P$. cyclopium Westling, $P$. solitum and several other names (Pitt 1979), but is best regarded as distinct (e.g., Frisvad and Samson 2004). Penicillium aurantiogriseum is listed as attacking onion and garlic in Sumner et al. (2008) and is reported from garlic in Brazil (Farr and Rossman n.d.). Penicillium cyclopium is regarded as a pathogen of onion in Snowdon (1992). One or more of these closely-related Penicillium spp. are listed on various plants (Allium, Gladiolus, Lilium, Tulipa, etc.) of the lily family (sensu lato) (Farr and Rossman n.d.), but such fungal names in older literature are unlikely to correspond precisely to the same names as applied under current taxonomic criteria. This situation is reminiscent of the name $P$. corymbiferum, applied in the past to a wider variety of taxa than would be admissible under current taxonomic criteria, and sometimes still applied (usually inappropriately) in more recent literature. The members of series Corymbifera in this study, $P$. albocoremium and $P$. radicicola, appear not to be previously recorded in North America (Farr and Rossman n.d.).

\subsection{Management implications}

Current commercial practices for onion vary, even for advanced agricultural economies. Typical for the United Kingdom is postharvest curing at 20-28 ${ }^{\circ} \mathrm{C}$ for up to six weeks (Chope et al., 2012), or for the PNW one to three weeks (Matson et al., 1985). After curing, onions are most usually stored under refrigerated conditions, often with modified atmospheres, but onions are also exposed to non-refrigerated conditions for up to several days during conditioning prior to packaging or pallet storage prior to shipping (Matson et al., 1985). Storage of garlic, iris and 
tulip bulbs also typically involves significant periods of exposure to non-refrigerated conditions (Gross et al., 2014). Such temperatures and times, approximate to our experimental conditions, could allow formation of lesions from several $\mathrm{mm}$ to several $\mathrm{cm}$, depending on the causal agent and host. Impact of blue mold clearly varies with species identity of the causal agent and host, therefore host rotation is a potential management option. Pre-planting fungicides have proven of some efficacy (Dugan et al. 2007), but we have no data indicating that Penicillium species causing blue mold of bulbs will strongly differ in response to a given fungicide, although isolates of a given species may develop resistance. Allium aflatunense and A. stipitatum (ornamental onions, subgenus Melanocrommyum, section Megaloprason) proved resistant to decay upon inoculation with Penicillium allii (Dugan et al. 2011), and A. stipitatum displayed discernible resistance here. The mechanism of this resistance is unknown.

\subsection{Summary and conclusions}

Results obtained herein deepen understanding of Penicillium spp. pathogenic in edible and ornamental bulbs. Results must be interpreted with caution because our collections have less depth (often only a single isolate per species from a given bulb crop) than corresponding collections of bulb-rotting isolates in Europe. Also, except for using a wounding tool, we did not attempt to mimic any predisposing factors that might sometimes occur during commercial processing, such as hot water treatment, suboptimal temperature control in drying sheds, wounding during lifting, etc. Moreover, given the world-wide movement of edible and ornamental bulbs, it is often uncertain whether a given taxon is indigenous to a given geographic region, merely endemic, or undetected. Limitations in seasonal availability and other constraints precluded challenge of all pertinent bulb crops, such as Narcissus. Nonetheless, the various 
Penicillium species inducing blue mold in the PNW clearly differ in host range and aggressiveness. Precise identification of such agents and determination of their host ranges should enable refinement of management strategies, such as crop rotation, postharvest storage and marketing.

\section{Acknowledgements}

The authors thank Lindsey du Toit for the isolate from onion 'Prince' seed, John Fellman for productive discussions, Chang-Lin Xiao and Weidong Chen for helpful comments on the manuscript, and Donna Ayling for technical assistance. The authors gratefully acknowledge financial support from the USDA Western Region Integrated Pest Management Competitive Grants Program, and the USDA-NIFA Specialty Crop Research Initiative No. 2010-01193.

\section{References}

Barreto, M.C., Houbraken, J., Samson, R.A., Frisvad, J.C., San-Romão, M.V. 2011. Taxonomic studies of the Penicillium glabrum complex and the description of a new species $P$. subericola. Fungal Diversity 49, 23-33.

Çakir, E., Maden, S. 2015. First report of Penicillium polonicum causing storage rot of onion bulbs in Ankara province, Turkey. New Disease Reports 32, 24.

Chen, A.J., Tang, D., Zhou, Y.Q., Sung, B.D., Li, X.J., Wang, L.Z., Gao, W.W. 2013. Identification of ochratoxin A producing fungi associated with fresh and dry liquorice. Plos One $8,1-13$.

Chope, G.A., Cools, K., Hammond, J.P., Thompson, A.J., Terry, L.A. 2012. Physiological, biochemical and transcriptional analysis of onion bulbs during storage. Ann. Bot. 109, 
$819-831$

Duduk, N., Vasic, M., Vico, I. 2014. First report of Penicillium polonicum causing blue mold on stored onion (Allium cepa) in Serbia. Plant Dis. 98, 1440.

Dugan, F.M., B.C. Hellier and S.L. Lupien. 2007. Pathogenic fungi in garlic seed cloves from the United States and China, and efficacy of fungicides against pathogens in garlic germplasm in Washington State. J. Phytopathol. 155, 437-445.

Dugan, F.M., Hellier, B.C., Lupien, S.L. 2011. Resistance to Penicillium allii in accessions from a National Plant Germplasm System Allium collection. Crop Prot. 30, 483-488.

Dugan, F.M., Lupien, S.L., Vahling-Armstrong, C.M., Chastagner, G.A., Schroeder, B.K. 2014. Host ranges of North American isolates of Penicillium causing blue mold of bulb crops. Crop Prot. 64, 129-136.

Farr, D.F., Rossman, A.Y. n.d. Fungal Databases, Systematic Mycology and Microbiology Laboratory, ARS, USDA. Retrieved January 21, 2016, from http://nt.arsgrin.gov/fungaldatabases/

Frisvad, J.C., Samson, R.A., 2004. Polyphasic taxonomy of Penicillium subgenus Penicillium: a guide to identification of food and air-borne terverticillate Pencillia and their mycotoxins. Stud. Mycol. 49, 1-173.

Frisvad, J.C., Andersen, B., Samson, R.A. 2007. Association of moulds to foods. In: J. Dijksterhuis, J., Samson, R.A. (Eds.), Food Mycology: A Multifaceted Approach to Fungi and Food, CRC Press, Boca Raton, Florida, pp 199-240.

Glass, N.L., Donaldson, G.C., 1995. Development of primer sets designed for use with the PCR to amplify conserved genes from filamentous ascomycetes. Appl. Environ. Microb. 61, $1323 \mathrm{e} 1330$. 
Gross, K.C., Wang C.Y., Saltveit, M. (Eds.) 2014. The Commercial Storage of Fruits, Vegetables and Florist and Nursery Stocks. USDA Handbook 66. www.ba.ars.usda.gov/hb66/.

Guevara-Suarez, M., Sutton, D.A., Cano-Lira, J.F., García, D., Martin-Vicente, A., Wiederhold, N., Guarro, J., Gené, J. In press. Penicillium-like fungi from clinical samples in the USA and their anti-fungal susceptibility. J. Clinical Microbiol. doi:10.1128/JCM.00960-16.

HemaMoorthy, T., Prakasam, V. 2013. First report of Penicillium expansum causing bulb rot of Lilium in India. American-Eurasian J. Agric. \& Environ. Sci. 13, 293-295,

Houbraken, J. López-Quintero, C.A., Frisvad, J.C., Boekhout, T., Theelen, B., Franco-Molano, A.E., Samson, R.A. 2011. Penicillium araracuarense sp. nov., Penicillium elleniae sp. nov., Penicillium penarojense sp. nov., Penicillium vanderhannenii sp. nov., and Penicillium wotroi sp. nov., isolated from leaf litter. Internat. J. System. Evol. Microbiol. $61,1462-1475$.

Houbraken, J., Visagie, C.M., Meijer, M., Frisvad, J.C., Busby, P.E., Pitt, J.I., Seifert, K.A., Louis-Seize, G., Demirel, R., Yilmaz, N., Jacobs, K., Christensen, M., Samson, R.A. 2014. A taxonomic and phylogenetic revision of Penicillium section Aspergilloides. Stud. Mycol. $78,373-451$.

Houbraken, J., Wang, L., Lee, H.B., Frisvad, J.C. 2016. New sections in Penicillium contaning novel species producing patulin, pyripyropens or other bioactive compounds. Personia 36, 299-314.

Ibatsam, K., Rukhsana, B., Nasim, G. 2012. Preservation of Penicillium species by lyophilization. African J. Food, Agric. Nutr. Devel. 12, 6055-6064. 
Khodaei, A., Arzanlou, M., Houbraken, J. 2015. Five new species of Penicillium and Talaromyces for mycobiota of Iran. Rastaniha 16(2), 186-199.

Lugauskas, A., Repeckiene, J., Novosinskas, H. 2005. Micromycetes, producers of toxins, detected on stored vegetables. Ann. Agric. Environ. Med. 12, 253-60.

Mansouri, S., Houbraken, J., Samson, R.A., Frisvad, J.C., Christensen, M., Tuthill, D.E., Koutaniemi, S., Hatakka, A., Lankinen, P. 2013. Penicillium subrubescens, a new species efficiently producing inulinase. Antonie van Leeuwenhoek 103, 1343-1357.

Matson, W.E., Mansour, N.S., Richardson, D.G. 1985. Onion storage guidelines for commercial growers. Pacific Northwest Extension PNW 277, 15 pp.

Oh, J.Y., Han, G.D., Jeong, J.J., Sang, M.K., Chun, S.C., Kim, K.D. 2015. First report of Penicillium georgiense as a fungal pathogen of onion (Allium cepa L.). Crop Prot. 72, 8389.

Overy, D.P, Frisvad, J.C. 2003. New Penicillium species associated with bulbs and root vegetables. System. Appl. Microbiol. 26, 631-639.

Overy, D.P., Frisvad, J.C., Steinmeier, U., Thrane, U. 2005a. Clarification of the agents causing blue mold storage rot upon various flower and vegetable bulbs: Implications for mycotoxin contamination. Postharvest Biol. Technol. 35, 217-221.

Overy, D.P., Karlshøj, K., Due, M.J. 2005b. Low temperature growth and enzyme production in Penicillium ser. Corymbifera species, causal agents of blue mold storage rot in bulbs. J. Plant Pathol. 87, 57-63.

Overy, D.P., Valdez, J.G., Frisvad, J.C., 2005c. Revisions to Penicillium ser. Corymbifera: agents responsible for blue mould storage rot of various flower and vegetable bulbs. Can. J. Bot. 83, 1422-1433. 
Park, M.S., Fong, J.J., Oh, S.-Y., Kwon, K.K., Sohn, J.H., Lim, Y.W. 2014. Marine-derived Penicillium in Korea: diversity, enzyme activity, and antifungal properties. Antonie van Leeuwenoek 106, 331-345.

Pitt, J.I. 1979. The Genus Penicillium and Its Teleomorphic States Eupenicillium and Talaromyces. Academic Press, London. 634 pp.

Pitt, J.I., 2000. A Laboratory Guide to Common Penicillium Species. Food Science Australia. CSIRO, North Ryde, NSW, 197 pp.

Piwani, A. 2007. Health status of two plantations of tulip near Pulawy and fungi isolated from foliar parts and bulbs. Electronic J Polish Agric. Universities 10(4) www.ejpau.media.pl/volume10/issue4/art-07.html

Samson, R.A., Seifert, K.A., Kuijpers, A.F.A., Houbraken, J.A.M.P., Frisvad, J.C. 2004. Phylogenetic analysis of Penicillium subgenus Penicillium using partial $\beta$-tubulin sequences. Stud. Mycol. 49, 175-200.

Sang, M.K., Han, G.D., Oh, J.Y., Chun, S.-C., Kim, K.D. 2014. Penicillium brasilianum as a novel pathogen of onion (Allium cepa L.) and other fungi predominant on market onion in Korea. Crop Prot. 65, 138-142.

Sanzani, S.M., Susca, A., Mastrorosa, S., Solfrizzo, M. 2016. Patulin risk associated with blue mould of pome fruit marketed in southern Italy. Quality Assurance and Safety of Crops and Foods. Published online: May 2016, 8 pages. DOI:

dx.doi.org/10.3920/QAS2015.0784.

Smalley, E.B., Hansen, H.N., 1962. Penicillium decay of garlic. Phytopathology 52, 666-678. Snowdon, A.L. 1992. Color Atlas of Post-Harvest Diseases and Disorders of Fruits and Vegetables Volume 2: Vegetables. CRC Press, Boca Raton, Florida. 416 pp. 
Sonjak, S., Frisvad, J.C., Gunde-Cimerman, N. 2005. Comparison of secondary metabolite production by Penicillium crustosum strains, isolated from Arctic and other various ecological niches. FEMS Microbiol. Ecol. 53, 51-60.

Stevens, C., Khan, V.A., Wilson, C.L., Lu, J.Y., Pusey, L., Bassett, C.L., Igwegbe, E.C.K., Wisniewski, M., Chalutz, E.; Droby, S., El-Ghaouth, A. 2006. Photobiological effects of radiation hormesis on the control of postharvest decay and delayed senescence and ripening of postharvest crops. In: Recent research developments in bioenergetics. Pandalai, S.G. (Ed.), Transworld Research Network Kerala: Transworld Research Network, pp. 4380.

Sumner, D.R., Langston, D.B., Seebold, K.W. 2008. Blue mold, In: Compendium of Onion and Garlic Diseases and Pests, $2^{\text {nd }}$ ed., Schwartz, H.F., Mohan, S.K. (Eds.), APS Press, St. Paul, Minnesota, pp. 52-53.

Varga, J., Houbraken, J., Samson, R.A., Frisvad, J.C. 2008. Molecular diversity of Aspergillus and Penicillium species on fruits and vegetables. In: Barkai-Golan, R., Paster, N. (Eds.), Mycotoxins in Fruits and Vegetables. Academic Press, London, pp. 205-223.

Visagie, C.M., Houbraken, J., Frisvad, J.C., Hong, S.-B., Klaassen, C.H.W., Perrone, G., Seifert, K.A., Varga, J., Yaguchi, T., Samson, R.A. 2014. Identification and nomenclature of the genus Penicillium. Stud. Mycol. 78, 343-371.

Yu, S.H., Oh, S.Y., Lee, H.B., Kim, B.R., Chung, L.M., Paik, S.B. 1997. Survey and control of the occurrence of mycotoxins from postharvest vegetables in Korea. I. Mycotoxins produced by Alternaria and Penicillium isolates from spice vegetables. Korea J. Plant Pathol. 13, 323-330. [In Korean, English abstract] 
Zhang, A., Schwartz, S., Wagner, L., Miller, W. 2000. A greedy algorithm for aligning DNA sequences. J. Comput. Biol. 7(1e2), 203e214. 


\section{APPENDIX A}

\begin{tabular}{|c|c|c|c|c|c|c|}
\hline $\begin{array}{l}\stackrel{\text { Host } \rightarrow}{\rightarrow} \rightarrow \\
\text { Penicillium species } \\
\text { and strain } \downarrow\end{array}$ & $\begin{array}{l}\text { garlic } \\
\text { Allium } \\
\text { sativum }\end{array}$ & $\begin{array}{l}\text { onion GP } \\
\text { A. сера }\end{array}$ & $\begin{array}{l}\text { onion forum } \\
\text { A. сера }\end{array}$ & $\begin{array}{l}\text { ornamental } \\
\text { onion } \\
\text { A. stipitatum }\end{array}$ & $\begin{array}{l}\text { iris } \\
\text { Iris } \\
\text { hollandica }\end{array}$ & $\begin{array}{l}\text { tulip } \\
\text { Tulipa }\end{array}$ \\
\hline $\begin{array}{l}\text { P. albocoremium } \\
\text { PenVDC-36:2013 sci1 }\end{array}$ & & & & & & \\
\hline Initial Test Date & $1 / 14 / 2016$ & $1 / 14 / 2016$ & $7 / 31 / 2014$ & $8 / 13 / 2015$ & $9 / 16 / 2015$ & 9/30/2015 \\
\hline inoculated & $11.69+/-0.88$ & $8.67+/-1.32$ & $6.03+/-2.00$ & $2.16+/-0.36$ & $2.22+/-0.46$ & $2.57+/-1.04$ \\
\hline control & $1.92+/-0.30$ & $1.60+/-0.26$ & $1.13+/-0.08$ & $1.88+/-0.25$ & $1.50+/-0.30$ & $1.31+/-0.17$ \\
\hline$P$ value $\mathrm{T}$-test & $P=0.000$ & $P=0.000$ & $P=0.001$ & $P=0.082$ & $P=0.001$ & $P=0.003$ \\
\hline$P$ value GLM & $P=0.000$ & $P=0.000$ & $P=0.000$ & $P=0.076$ & $P=0.000$ & $P=0.000$ \\
\hline Repeated Test Date & $5 / 27 / 2016$ & $5 / 27 / 2016$ & $5 / 27 / 2016$ & 09/17/2015 & $5 / 27 / 2016$ & 10/16/2015 \\
\hline inoculated & $8.87+/-0.72$ & $7.13+/-0.52$ & $7.11+/-1.58$ & $3.43+/-0.87$ & $2.17+/-0.40$ & $2.10+/-0.71$ \\
\hline control & $3.14+/-2.67$ & $1.83+/-1.93$ & $1.56+/-1.05$ & $2.22+/-0.26$ & $1.18+/-0.15$ & $1.31+/-0.19$ \\
\hline$P$ value T-test & $P=0.000$ & $P=0.000$ & $P=0.000$ & $P=0.001$ & $P=0.001$ & $P=0.006$ \\
\hline$P$ value GLM & $P=0.000$ & $P=0.000$ & $P=0.000$ & $P=0.000$ & $P=0.000$ & $P=0.001$ \\
\hline
\end{tabular}

P. crustosum Pen YC\#1:2011 sci1 Initial Test Date inoculated control $P$ value T-test

$P$ value GLM

Repeated Test Date inoculated control

$P$ value T-test

$P$ value GLM

$1 / 28 / 2015$
$1.62+/-0.30$
$1.50+/-0.36$
$P=0.438$
$P=0.818$

$2 / 11 / 2015^{*}$
$2.02+/-0.36$
$1.62+/-0.19$
$P=0.013$
$P=0.589$

$12 / 11 / 2014$

$1.16+/-0.47$ $0.68+/-0.12$

$P=0.008$

$P=0.331$

$P=0.203$

$1 / 14 / 2015 *$

$0.82+/-0.23$

$0.63+/-0.08$

$P=0.028$

$P=0.618$

\section{$1 / 15 / 2015$}

$0.84+/-0.23$

$0.65+/-0.05$

$P=0.026$

$P=0.730$

\section{$8 / 13 / 2015$}

$2.14+/-0.22$

$1.97+/-0.43$

$P=0.301$

$P=0.255$

9/17/2015

$1.70+/-0.24$

$1.80+/-0.37$

$P=0.501$

$P=0.609$
$9 / 16 / 2015$

$1.69+/-0.40$

$1.42+/-0.15$

$P=0.090$

$P=0.041$

$11 / 12 / 2015^{\S}$

$1.80+/-0.27$

$1.50+/-0.19$

$P=0.001$

$P=0.044$
9/30/2015

$1.36+/-0.17$

$1.33+/-0.16$

$P=0.775$

$P=0.898$

$10 / 16 / 2015$

$1.17+/-0.19$

$1.35+/-0.09$

$P=0.016$

$P=0.433$

P. expansum Pen 347-W:2010 sci1 Initial Test Date inoculated control $P$ value T-test $P$ value GLM

Repeated Test Date inoculated control $P$ value T-test

$1 / 28 / 2015 *$

$1.70+/-0.15$

$1.56+/-0.24$

$P=0.086$

$P=0.793$

$2 / 11 / 2015$

$3.27+/-2.28$

$1.39+/-0.09$

$P=0.008$

$P=0.010$
$11 / 20 / 2014$

$0.99+/-0.28$

$0.72+/-0.11$

$P=0.020$

$P=0.442$

$1 / 14 / 2015$

$0.71+/-0.10$

$0.62+/-0.07$

$P=0.041$

$P=0.805$
$12 / 11 / 2014$

$0.95+/-0.19$

$0.75+/-0.13$

$P=0.020$

$P=0.683$

$1 / 15 / 2015$

$1.53+/-2.13$

$0.64+/-0.07$

$P=0.219$

$P=0.107$
$8 / 13 / 2015$

$1.87+/-0.37$

$2.00+/-0.29$

$P=0.424$

$P=0.392$

9/17/2015

$1.77+/-0.42$

$1.51+/-0.22$

$P=0.132$

$P=0.193$
9/16/2015

$2.13+/-0.32$

$1.38+/-0.19$

$P=0.000$

$P=0.000$

$11 / 12 / 2015$

$2.52+/-0.64$

$1.70+/-0.25$

$P=0.002$

$P=0.000$
9/30/2015

$2.11+/-0.44$

$1.32+/-0.19$

$P=0.000$

$P=0.000$

$10 / 16 / 2015$

$2.30+/-0.64$

$1.32+/-0.17$

$P=0.001$

$P=0.000$ 
P. glabrum

O. Pen\#15:2011 sci2

Initial Test Date

inoculated

control

$P$ value T-test

$P$ value GLM

Repeated Test Date

inoculated

control

$P$ value T-test

$P$ value GLM

\section{$P$. paraherquei}

Pen 308-N:2010 sci1

Initial Test Date

inoculated

control

$P$ value T-test

$P$ value GLM

Repeated Test Date

inoculated

control

$P$ value T-test

$P$ value GLM

$P$. polonicum
Pen1:2010 sci1
Initial Test Date
inoculated
control
$P$ value T-test
$P$ value GLM
Repeated Test Date
inoculated
control
$P$ value T-test
$P$ value GLM

garlic

$1 / 28 / 2015$

$3.83+/-2.36$

$1.61+/-0.35$

$P=0.016$

$P=0.000$

$2 / 11 / 2015$

$2.99+/-0.35$

$1.68+/-0.17$

$P=0.000$

$P=0.078$

$1 / 28 / 2015$
$2.26+/-0.60$
$1.44+/-0.31$
$P=0.004$
$P=0.145$
$2 / 11 / 2015$
$2.77+/-1.44$
$1.58+/-0.23$
$P=0.026$
$P=0.099$

\section{$11 / 20 / 2014$}

$0.78+/-0.24$

$0.74+/-0.09$

$P=0.633$

$P=0.908$

\section{$1 / 14 / 2015$}

$0.80+/-0.20$

$0.65+/-0.05$

$P=0.048$

$P=0.685$

$1 / 28 / 2015$
$9.19+/-0.89$
$1.73+/-0.27$
$P=0.000$
$P=0.000$
$2 / 11 / 2015$
$10.33+/-1.25$
$1.98+/-0.40$
$P=0.000$
$P=0.000$

$11 / 20 / 2014$
$6.22+/-1.84$
$1.04+/-0.13$
$P=0.000$
$P=0.000$
$1 / 14 / 2015$
$5.72+/-1.96$
$0.67+/-0.06$
$P=0.000$
$P=0.000$

onion forum

$12 / 11 / 2014$

$0.88+/-0.23$

$0.71+/-0.07$

$P=0.046$

$P=0.736$

$1 / 15 / 2015$

$0.90+/-0.16$

$0.68+/-0.06$

$P=0.001$

$P=0.685$

$12 / 11 / 2014$

$8 / 13 / 2015$

$1.81+/-0.33$

$0.93+/-0.27$

$0.63+/-0.05$

$1.78+/-0.19$

$P=0.005$

$P=0.784$

$P=0.546$

$P=0.830$

\section{$1 / 15 / 2015$}

9/17/2015

$0.83+/-0.27$

$1.76+/-0.25$

$0.63+/-0.03$

$1.69+/-0.39$

$P=0.032$

$P=0.665$

$P=0.710$
$9 / 16 / 2015$

$1.60+/-0.25$

$1.27+/-0.11$

$P=0.002$

$P=0.011$

$11 / 12 / 2015$

$1.72+/-0.25$

$1.64+/-0.19$

$P=0.449$

$P=0.598$

$\begin{array}{ll}12 / 11 / 2014 & 8 / 13 / 2015 \\ 4.21+/-2.65 & 1.92+/-0.38 \\ 0.75+/-0.29 & 1.96+/-0.31 \\ P=0.000 & P=0.844 \\ P=0.000 & P=0.830 \\ & \\ 1 / 15 / 2015 & 9 / 17 / 2015 \\ 7.09+/-1.12 & 1.89+/-0.17 \\ 0.76+/-0.10 & 1.98+/-.038 \\ P=0.000 & P=0.541 \\ P=0.000 & P=0.650\end{array}$

\section{$9 / 16 / 2015$}

$1.50+/-0.20$

$1.46+/-0.24$

$P=0.678$

$P=0.731$

$11 / 12 / 2015$

$2.04+/-0.28$

$1.66+/-0.26$

$P=0.010$

$P=0.009$
9/30/2015

$1.34+/-0.18$

$1.29+/-0.13$

$P=0.476$

$P=0.749$

$10 / 16 / 2015$

$1.31+/-0.18$

$1.40+/-0.20$

$P=0.345$

$P=0.687$
9/30/2015

$1.46+/-0.17$

$1.38+/-0.19$

$P=0.396$

$P=0.654$

$10 / 16 / 2015$

$1.58+/-0.71$

$1.39+/-0.52$

$P=0.528$

$P=0.393$ 


\begin{tabular}{|c|c|c|c|c|c|c|}
\hline $\begin{array}{l}\text { P. radicicola } \\
\text { Pen CB\#1:2011 sci2 }\end{array}$ & garlic & onion GP & onion forum & $\begin{array}{l}\text { ornamental } \\
\text { onion }\end{array}$ & iris & tulip \\
\hline Initial Test Date & $1 / 28 / 2015$ & $11 / 20 / 2014$ & $12 / 11 / 2014$ & $8 / 13 / 2015$ & $9 / 16 / 2015$ & 9/30/2015 \\
\hline inoculated & $6.08+/-3.13$ & $4.33+/-1.41$ & $5.33+/-2.27$ & $2.01+/-0.26$ & $1.84+/-0.31$ & $1.64+/-0.38$ \\
\hline control & $1.79+/-0.46$ & $0.75+/-0.10$ & $0.64+/-0.07$ & $1.99+/-0.40$ & $1.53+/-0.30$ & $1.42+/-0.16$ \\
\hline$P$ value T-test & $P=0.001$ & $P=0.000$ & $P=0.000$ & $P=0.893$ & $P=0.045$ & $P=0.135$ \\
\hline$P$ value GLM & $P=0.000$ & $P=0.000$ & $P=0.000$ & $P=0.872$ & $P=0.018$ & $P=0.202$ \\
\hline Repeated Test Date & $2 / 11 / 2015$ & $1 / 14 / 2015$ & 1/15/2015 & $9 / 17 / 2015$ & & 10/16/2015 \\
\hline inoculated & $6.21+/-3.75$ & $1.50+/-0.63$ & $3.79+/-2.69$ & $2.06+/-0.41$ & $1.91+/-0.37$ & $2.72+/-1.00$ \\
\hline control & $1.77+/-0.23$ & $0.69+/-0.08$ & $0.71+/-0.06$ & $2.09+/-0.43$ & $1.57+/-0.27$ & $1.42+/-0.23$ \\
\hline$P$ value T-test & $P=0.003$ & $P=0.002$ & $P=0.004$ & $P=0.866$ & $P=0.039$ & $P=0.001$ \\
\hline$P$ value GLM & $P=0.000$ & $P=0.033$ & $P=0.000$ & $P=0.865$ & $P=0.021$ & $P=0.000$ \\
\hline
\end{tabular}

$\S=$ Replications as well as treatment were significant in the repeat test.

$*$ = Quiescent fungi or problems with viability interfered with re-isolation of inoculated agent in one of two trials, but symptoms, including sporulation of the causal agent, were apparent in both trials. 